\title{
The Effect of Two Types of Feedback on Iranian EFL Learners' Tense-marker Production
}

\author{
Somayeh Kazemi Tari \\ (Islamic Azad University, Qaemshahr Branch, Iran) \\ doi:10.7575/aiac.alls.v.2n.1p.108
}

\begin{abstract}
Although many researchers have worked on the role of feedback in immersion programs on second language learners' production, still little is known about the role of different types of immediate feedback on the grammatical accuracy of learners' production. When, where and with who different types of immediate feedback such as prompts and recasts and their different subcategories might be appropriate? The purpose of the present research was to know which types of immediate oral feedback could better help Iranian EFL learners to produce the correct form of the tense markers of their target language-English. One of the primary objectives of the present study was to examine the effects of two types of oral feedback — namely explicit correction and implicit or-choice feedback — on Iranian EFL learners' production of different tense markers in English. The results were in favor of explicit correction over implicit or-choice feedback in helping learners to produce correct grammatical tense markers.
\end{abstract}

\section{Introduction}

The use of feedback in language teaching is nothing new. Traditional language teachers immediately corrected their students' errors when they appeared in their utterances. There are different views regarding the use of different types of feedback. Interlanguage researchers argue that errors should be tolerated as much as they are the result of the learner's communicative strategies. Another view is that errors should be ignored on the whole. Still another view is that some types of errors should be corrected. Ellis (1990) provides taxonomy of the type of errors that should be corrected by the teacher. According to Ellis (1990, pp. 5455), global errors, errors that affect the overall comprehensibility of an utterance, stigmatized errors, and errors relating to the learner's next stage of development should be corrected. 
There are a number of studies that have elicited teachers' rationales for correcting errors. Chaudron's (1986, in Chaudron, 1998, p. 136) research is among those. He compared the corrections made by teachers in French immersion classes in Canada and found that teachers corrected more "grammatical" (morphological and syntactic) errors in French classes (average 77\%) than in other classes (average 37\%). Also, Chaudron (1986, in Ellis, 1990, p. 73) found that fewer discourse errors were corrected compared to morphological errors.

Although the terms "feedback" and "correction" are usually used interchangeably, but Long (1977, cited in Ellis, 1990, p. 71) suggests the term "feedback" be used for the teacher's information about the correctness of the learner's utterances, while the term "correction" be used for the effect of feedback on learning. Ellis (1990, p. 71) uses error treatment and corrective feedback synonymously and states that the broadest definition of treatment is "any reaction by the teacher that clearly transforms, disapprovingly refers to or demands improvement."

Correction may not always be effective; in order for the correction to be effective some prerequisite must be met. Johnston (1988) states that correction is effective when:

1. The learner desires or needs to eradicate the mistake.

2. She is able to form an internal representation of what the correct behavior looks like.

3. She realizes that her performance is flawed.

4. She has the opportunity to perform in real condition. (cited in Ellis, 1990, p. 181)

Feedback to learners can be either explicit through overt correction or implicit through negotiation work. Negotiation and interaction are important in L2 learning because as Mackey and Philp (1998, in Kaplan, 2002, pp. 172-76) have shown interaction can provide modified speech, confirmation check, comprehension check, clarification request, or-choice, topic-focused, elaboration, on the spot learning, delayed learning, and testing a hypothesis. And according to Mitchell and Myles (2004, p. 195) language learning is highly "dependent on face to face interaction and shared processes, such as joint problem solving and discussion."

There are different types of feedback compiled by Lightbown and Spada (2006), Ellis (1994), Ellis (2003), and Doughty and Long (2003). Nassaji provides three types of focus of form feedback: non-negotiated feedback, limited negotiation feedback, and extended negotiation 
feedback (cited in Fotos \& Nassaji, 2007, pp. 123-24). Brown (2007, pp. 277-78) has provided taxonomy of six types of feedback that includes recast, clarification request, metalinguistic feedback, elicitation, explicit correction, and repetition. Among these six types of feedback, four types (i.e. clarification request, repetition, metalinguistic clues, and elicitation) are related to prompts. These four types of prompts have one crucial feature in common: "They withhold correct forms (and other signs of approval) and instead offer learners an opportunity to self-repair by generating their own modified response" (Lyster, 2004, p. 405).

Among different types of feedback one type that has had too many contradictory results on the learners' learning behavior is "recast". Recast is "an implicit type of corrective feedback that reformulates or responds an ill-formed or incomplete utterance in an unobtrusive way" (Brown, 2007, p. 277). Lyster (1998, in Kaplan, 2002, p. 177) found that learners could not decipher whether recasts were signs of correction or approval. Lyster and Ranata (1997, in Kaplan, 2002, p. 177) also found that recasts did not have immediate effect on subsequent production. But Mackey and Philp (1998, cited in Kaplan, 2002, p. 177) considering delayed effects of feedback showed that recasts had positive effect on learners' production.

Comparing the effects of recasts and prompts, Ammar (2008) found superior effects for prompts over recasts in the acquisition of possessive determiners by Francophone learners of English as a second language. She also found that prompts were particularly effective for lower proficiency learners, whereas higher proficiency learners appeared to benefit similarly from both recasts and prompts. Lyster (2004) explains the four types of prompt used in French immersion classes mentioned before as follows:

1. Clarification requests are phrases such as "Pardon me" and "I don't understand" used to indicate that the student's message has either been misunderstood or ill formed. For example:

Student: Et le coccinelle . . "And the (M) ladybug."

Teacher: Pardon? "Sorry?"

Student: La coccinelle . . "The (F) ladybug."

2. Repetitions replicate the student's error verbatim, usually with rising intonation and stress to highlight the error. For example: 
Student: La chocolat . . " (F) Chocolate."

Teacher: La chocolat? "(F) Chocolate?”

Student: Le chocolat. "(M) Chocolate."

3. Metalinguistic clues provide comments, information, or questions related to the wellformedness of the student's utterance. For example:

Student: Parce qu'elle cherche, euh, son, son carte.

"Because she's looking for, um, her, her (M) card."

Teacher: Pas son carte. "Not her (M) card."

Student: Euh, sa carte? "Um, her (F) card?"

4. Elicitation entails direct questions such as "How do we say that in French?" or pauses that allow students to complete the teacher's utterance. For example:

Teacher: Il vit où un animal domestique? Où est-ce que ça vit?

"Where does a pet live? Where does it live?"

Student: Dans un maison. "In a (M) house."

Teacher: Dans . . . ? Attention. "In . . . ? Careful."

Student: Dans une maison. "In a (F) house." (p. 405)

Finally, Brown (2007, p. 278) classifies responses to feedback into three types: (1) uptake, (2) repair, and (3) repetition.

\section{Research questions}

This study aims to test the effect of two types of feedback (i.e. explicit correction and elicitation), which are hypothesized to trigger different degrees of cognitive processing and awareness. The research questions are thus formulated as follows:

1. Will the use of explicit and implicit feedback in class improve Iranian EFL students' ability to accurately apply English tense markers?

2. Which type of feedback is more effective- explicit correction or implicit or-choice feedback? 


\section{Research hypotheses}

To find answers to the above mentioned questions the following null hypotheses were formulated:

1. The use of explicit and implicit feedback in class will not improve Iranian EFL students' ability to accurately apply English tense markers?

2. Explicit correction feedback is not more effective than or-choice feedback on Iranian EFL learners' production of tense markers.

\section{Method}

\section{Participants}

The participants in this study were females EFL students $(n=30)$ divided into two classes of 15. The students were all beginners. They received feedback on tense markers for 10 sessions. Each of the two groups received a particular type of feedback. One group, designated as the explicit correction group (Group A), received explicit correction following their errors in tense markers, whereas the other group designated as the implicit or-choice group (Group B), received or-choice feedback following errors in tense markers.

\section{Procedures}

Before instructional period, students received a fill-in-the-blank pretest and after the instruction they received the same test as posttest (see Appendix A). During the ten-session instructional period, students in the two groups received different types of feedback for 10 sessions. Each session some sentences that included one of the simple present, simple past and present continuous tenses were extracted from one unit of the Intro book (Richards, 1997) and their structures were practiced by the students. For examples of these structures see Table 1 below.

Table 1: Structures with simple present, simple past and present continuous tenses

\begin{tabular}{ll}
\hline Tense markers & Structures \\
\hline Simple present & Wh-questions and statements with be \\
& Simple present Wh-questions and statements \\
& Yes/No and Wh-questions with do \\
& Questions with how \\
Simple past & Wh-questions and statements with be \\
& Simple past Wh-question and statements \\
& Past tense of be \\
Present continuous & Yes/No and Wh-questions and statements \\
\hline
\end{tabular}


Then, the researcher asked the students some oral questions to elicit the tense markers that were practiced on the same session or the sessions before. At the end of each session, the students were asked to make dialogues about their own experiences using the structures worked out on the same day and role play it in the class. During the whole class time students' tense marker errors were immediately corrected in both groups. The explicit correction group (Group A) received Type A feedback (i.e. explicit error correction) and the implicit or-choice group (Group B) received Type B feedback (i.e. or-choice feedback). Examples of Type A and Type $B$ feedbacks for some errors extracted from teacher-student interaction in class are presented in Table 2.

Table 2: Type $A$ and Type $B$ feedback with some examples extracted from teacherstudent interaction

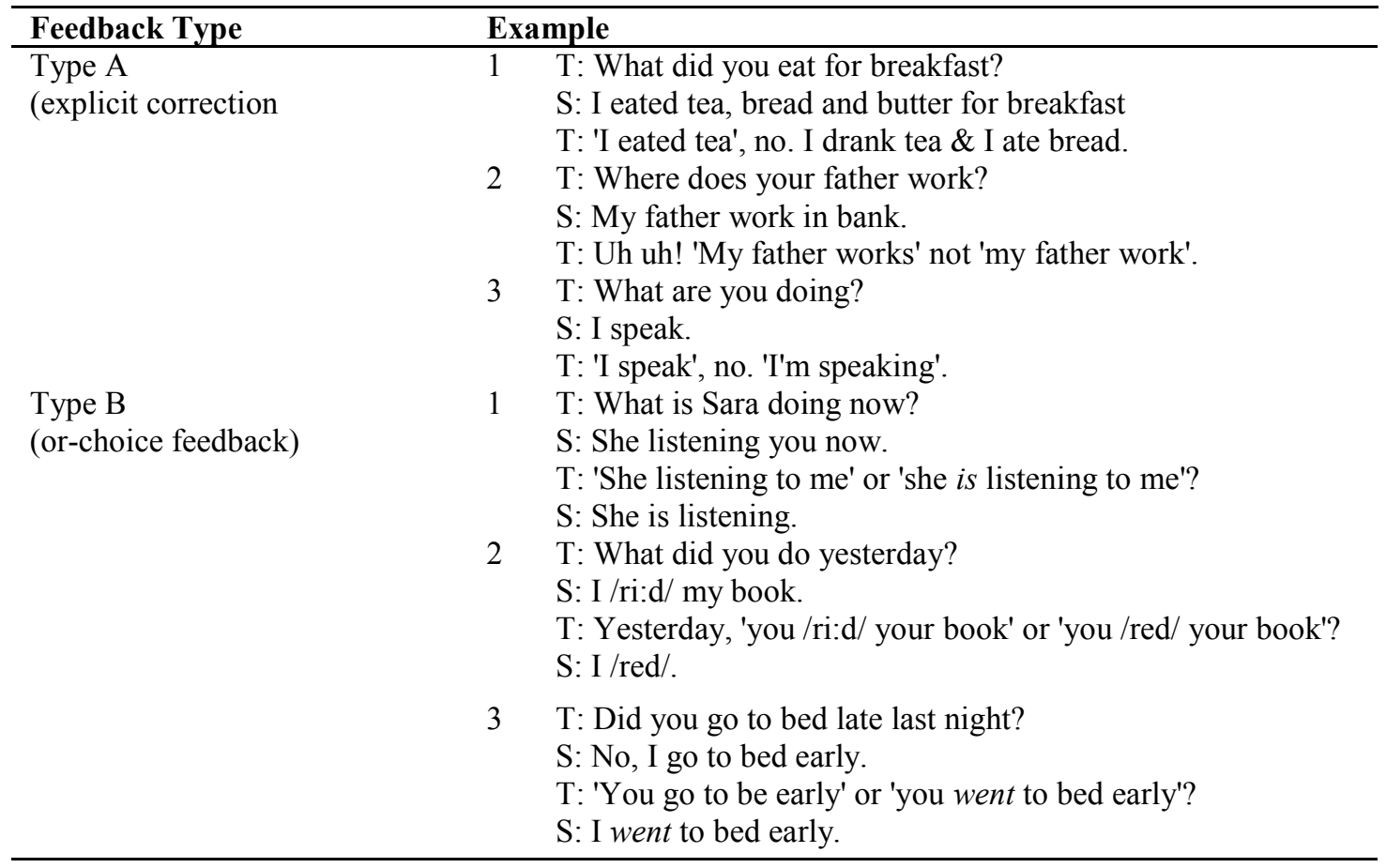

\section{Target features}

To select the 3 target tense markers used in this study, the researcher analyzed the students' course book and selected the most frequent tense markers appearing in these materials. These tense markers are presented in Table 3 with a few examples for each. 
Table 3: Tense markers along with a few examples

\begin{tabular}{|c|c|}
\hline Tense Markers & Examples \\
\hline Simple present & $\begin{array}{l}\text { They play football everyday. } \\
\text { She plays the piano. }\end{array}$ \\
\hline Simple past & $\begin{array}{l}\text { I walked home yesterday. } \\
\text { She went to the office. } \\
\text { I read (pronounced /red/) an English book this morning. }\end{array}$ \\
\hline Present continuous & $\begin{array}{l}\text { I } \underline{\operatorname{am}} \text { writing a story. } \\
\text { She is smiling. } \\
\text { They are listening to the teacher. }\end{array}$ \\
\hline
\end{tabular}

\section{Treatment materials}

Ten topics were selected from among the students' course book material. The material, which included different topics such as greeting, daily schedule, clothes, families, and past experiences, provided the communicative context for the present study. For the purposes of this study, the topics for discussing and practicing different grammatical forms in the class were selected from Intro, an international communication book written by Richards (1997). The conversations and grammar exercises included in the book provided the context for drawing students' attention to the three tense markers which were the focus of the present study.

\section{Measures}

The students' ability to use accurate tense markers was assessed by using a written 20-item fill-in-the-blank test for which they were given 25 minutes to complete. The same test was used both as pretest and posttest. By comparing the pretest-posttest results with two t-tests the effectiveness of each type of feedback was measured. Then another t-test was used to compare the results of the two posttests to see which feedback was more effective.

Before the introduction of the study, in a pilot study conducted by the researcher, the 20 -item teacher-made test was administered to a group of 15 students at the same level with the students in the researcher's classes to measure the reliability of the teacher-made test. By using the Kuder-Richardson formula, the researcher measured the reliability of the test to be about 0.70 . The measured reliability was within an acceptable range. 


\section{Results and discussion}

The means and standard deviations of the pretests and posttests of the two groups are shown in Tables 4 and 5. Also, Figure 1 shows the means of the pretests and posttests for Group A and Group B.

Table 4: Pretest means (M) and standard deviations (SD) for the two groups

\begin{tabular}{|c|c|c|c|}
\hline \multicolumn{2}{|c|}{${\text { Group } A^{1}(n=15)}$} & \multicolumn{2}{|c|}{${\text { Group } B^{2}(n=15)}$} \\
\hline $\mathbf{M}$ & SD & $\mathbf{M}$ & SD \\
\hline 6.8 & 2.8 & 6.4 & 2.9 \\
\hline
\end{tabular}

Table 4 shows that the means for the two groups on the pretest have no significant difference: $\mathrm{t}=0.39, \mathrm{p}<0.05$. This confirms that the two groups were essentially equivalent before the instruction started. From Figure 1, it is quite evident that the posttest means are significantly higher than the pretest means: $\mathrm{t}=6.92, \mathrm{p}<0.05$ for Group $\mathrm{A}$, and $\mathrm{t}=4.30, \mathrm{p}<0.05$ for Group $\mathrm{B}$. This shows that both types of feedback (i.e. Group A feedback and Group B feedback) improved the students' accurate use of tense markers in English.

The means of the two groups on posttest, shown in Table 5 and also evident in Figure 1 show that the explicit correction group outperformed the or-choice group on the posttest: $\mathrm{t}=2.12$, $\mathrm{p}<0.05$.

Table 5: Posttest means (M) and standard deviations (SD) for the two groups

\begin{tabular}{lclc}
\hline & Group $A^{1}(n=15)$ & & Group B $^{2}(\mathrm{n}=15)$ \\
\hline M & SD & M & SD \\
12.3 & 1.4 & 10.1 & 1.8 \\
\hline
\end{tabular}

${ }^{1}$ Group A: explicit correction group

${ }^{2}$ Group B: or-choice group 


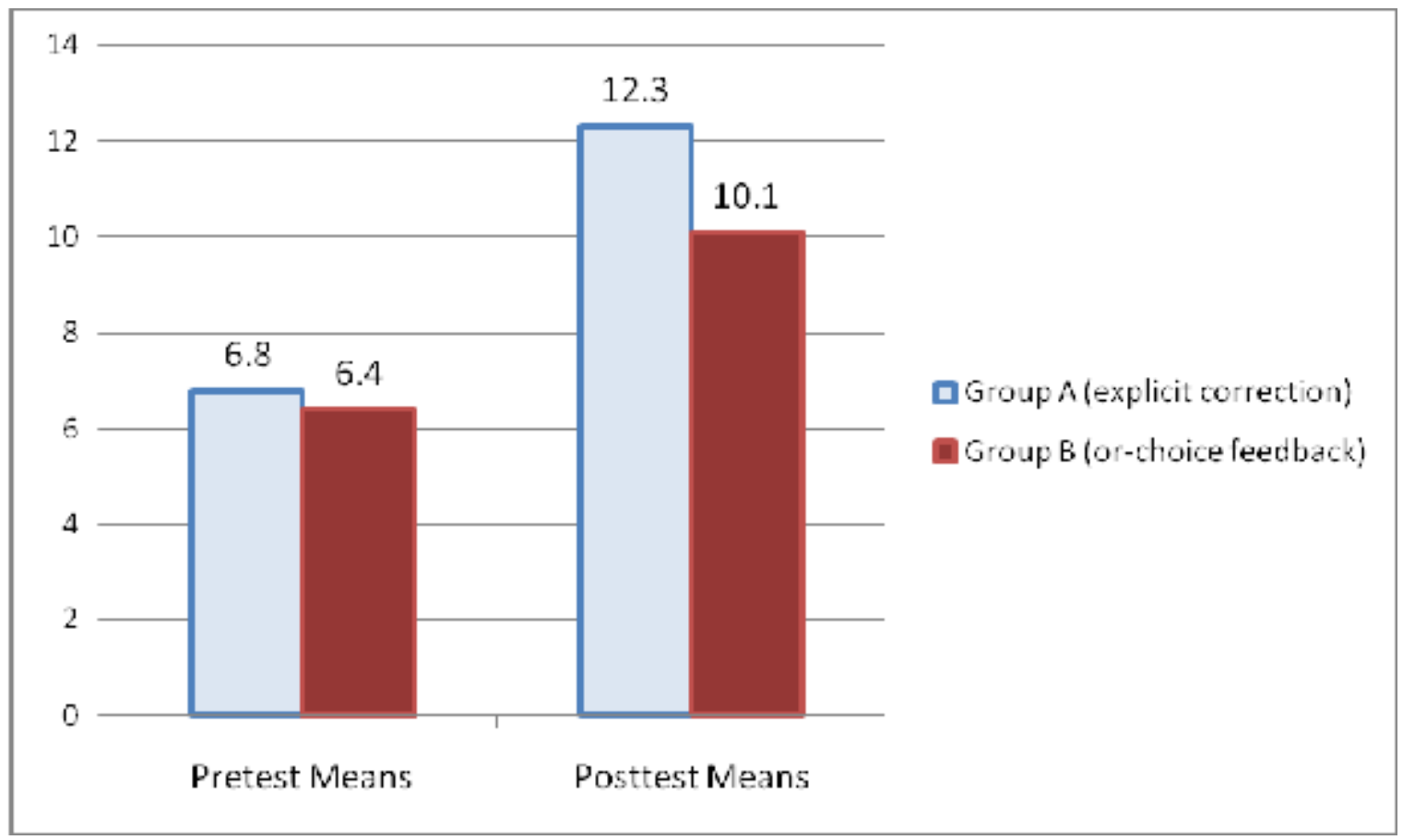

Figure 1: The pretest and posttest means for groups A and B

The results of the t-tests rejected the first and second null hypotheses, thus confirming the effectiveness of the two types of feedback, and approving the superiority of the Type A feedback over Type B feedback on Iranian EFL learners' production.

The present study thus contributes to the arguments about the benefit of different types of corrective feedback by confirming that explicit correction is more beneficial compared to orchoice feedback to the beginner Iranian EFL learners in communicatively oriented classrooms. In terms of pedagogical implications, these findings may not be generalizable to other instructional contexts. 


\section{References}

Ammar, A. (2008). Prompts and recasts: Differential effects on second language morphosyntax. Language Teaching Research, 12(2), 183-210.

Brown, H. D. (2007). Principles of language learning and teaching $\left(5^{\text {th }}\right.$ ed.). New York: Pearson Education.

Chaudron, C. (1998). Second language classrooms: Research on teaching and learning. Cambridge: Cambridge University Press.

Doughty, C. J., \& Long, M. H. (Eds.). (2003). The handbook of second language acquisition. New York: Blackwell.

Ellis, R. (1990). Instructed second language acquisition. Oxford: Basil Blackwell.

Ellis, R. (1994). The study of second language acquisition. Oxford: Oxford University Press.

Ellis, R. (2003). Task-based language learning and teaching. Oxford: Oxford University Press.

Fotos, S., \& Nassaji, H. (Eds.). (2007). Form-focused instruction and teacher education: Studies in honor of Rod Ellis. Oxford: Oxford University Press.

Kaplan, R. B. (Ed.). (2002). The Oxford handbook of applied linguistics. Oxford: Oxford University Press. Lightbown, P.M., \& Spada, N. (2006). How languages are learned ( $3^{\text {nd }}$ ed.). Oxford: Oxford University Press. Lyster, R. (2004). Differential effects of prompts and recasts in Form-focused instruction. SSLA, 26, 399-432.

Mitchell, R., \& Myles, F. (2004). Second language learning theories. London: Arnold.

Richards, J. C. (1997). Intro. Cambridge: Cambridge University Press.

\section{Appendix A: Pretests and Posttests}

Complete these conversations using the correct form of the verb forms in parentheses.

1. A: What (do) you do?

B: I'm a student. I study English.

A: What (do) your mother do?

B: She is a teacher. She

A: Is your father a teacher, too?

$\mathrm{B}$ : No, he is a doctor. He (teach) English at a school in Chicago.

2. A: Is your sister looking for a job?

B: Yes, she is. She (love) acting

3. A: (do) you (work) in a restaurant now, but she (work) in a hospital.

B: Yes, I I (do) anything special over the weekend?

4. A: What

B: I (do) you (go) shopping. I (spend) all my money. Now I don't have any money. (see) the new Tom Cruise film. I (do) last night?

5. A: (be) you in France last summer? (love) it!

B: Yes, I (be).

A: How long (be) you there?

B: I (stay) there for a month. 